\title{
INSIDER TRADING IN THE GLOBAL ECONOMIC ENVIRONMENT: ELEMENTS OF CRIMINAL LIABILITY
}

\author{
Dmitriy V Kamensky \\ Department of Legal Courses, \\ Berdyansk State Pedagogical University, Berdyansk, Ukraine
}

Olexandr O Dudorov

Department of Criminal Law Courses,Luhansk State University of Internal Affairs named after E.O. Didorenko, Sievierodonetsk, Ukraine

\section{Roman O Movchan}

Department of Constitutional, International and Criminal law, Donetsk National University named after Vasyl Stus, Vinnytsia, Ukraine

\author{
Andrii A Vozniuk \\ Laboratory on Issues of Combating Crime,National Academy of Internal Affairs \\ Kyiv, Ukraine \\ Tamara P Makarenko \\ Faculty of the Humanities and Economics,Berdyansk State Pedagogical University \\ Berdyansk, Ukraine
}

\begin{abstract}
The article addresses emerging issues of criminal liability for insider trading within the global economic environment. Based on comparative analyses of Ukrainian and American approaches toward understanding the nature and negative consequences of insider trading for the national stock markets, key research pragmatic conclusions are formulated. A general conclusion elaborates on the idea that the level of effectiveness of criminal law protection of Ukrainian stock market not at least depends on the textual quality of the insider trading provision of the Criminal Code of Ukraine (Art. 232-1), which describes key elements of the offense and also connects the Criminal Code norm with the regulatory framework on stock market operation.

Analysis of American, Ukrainian and, to a lesser extent, other European experience in combating insider abuse suggests that improvement of the national stock market legislation should be exercised in different directions, among which: increasing transparency in the activities and management of joint stock companies; tightening


requirements for reporting and disclosure for business entities, whose shares and other securities circulatt on stock market; providing investors with unimpeded access to documents and information about large shareholders; increased attention to transactions with the company's shares carried out by its employees; prohibition on combining auditing and consulting functions within one company, etc. Such measures should not excessively intersect the realm of criminal law relations, otherwise this might lead to the collapse of the stock market protection framework.

Key words: insider trading, white collar crime, Criminal Code of Ukraine, stock index, stock exchange, securities, insider information

Cite this Article: Dmitriy V Kamensky, Olexandr O Dudorov, Roman O Movchan, Andrii A Vozniuk and Tamara P Makarenko, Insider Trading in The Global Economic Environment: Elements of Criminal Liability, International Journal of Management, 11(12), 2020, pp 1679-1688. http://iaeme.com/Home/issue/IJM?Volume=11\&Issue=12

\section{INTRODUCTION}

After several centuries of development, a few crises and financial turmoils, stock markets are no longer associated merely with the artificial capital in public mind, and as the basis of the market economy, have become real mechanisms for attracting investment, evaluating proprietary rights for assets. To a large extent, this has become the summing up of a peculiar compromise: secutiry issuers, investors, regulators agree that the policy of non-transparency and double standards in the stock market is inefficient, and countering manipulation of prices for financial instruments and insider deals as well as adequate enforcement practices with regard to investor rights' violations are not merely of critical importance for the stock markets, but also serve as the institutional footing for their effectiveness and viability.

Indeed, over the past three decades, the history of stock market establishment and development in Ukraine has provided numerous examples of the global best practices' transfer with regards to stock exchanges' supervision and organization, depository and clearing infrastructure etc. However in reality, though stock market is the driving force of the global economy, it poorly performs the functions of deployment, allocation and channeling of financial resources in Ukraine with the goal of stimulating economic growth and attracting foreign investment. Despite a few positive examples of integration into global capital markets (in particular, the recent provision with the access to the Ukrainian state bonds for foreign investors via the Clearstream international depository and also admission of the U.S. Treasury Bonds and Apple stocks), Ukrainian stock market is plagued by significant distortions and imbalances, it remains underdeveloped and unattractive for both domestic and foreign investors. This is clearly evidenced by economic data.

Among major reasons for this remain the incoherence of legislative changes, fragmentary nature and inconsistency in the implementation of the European legal framework, certain chaotic nature of regulation and absent consideration of objective factors of the immature national capital market functioning, which includes challenges of fair stock pricing. Due to a number of factors (total illiquidity, lack of economic interest among issuers and investors in attracting and allocating capital, irregularity of trading sessions, market volatility at large), there are no conditions for establishing fair prices for the majority of financial instruments in Ukraine [2]. 


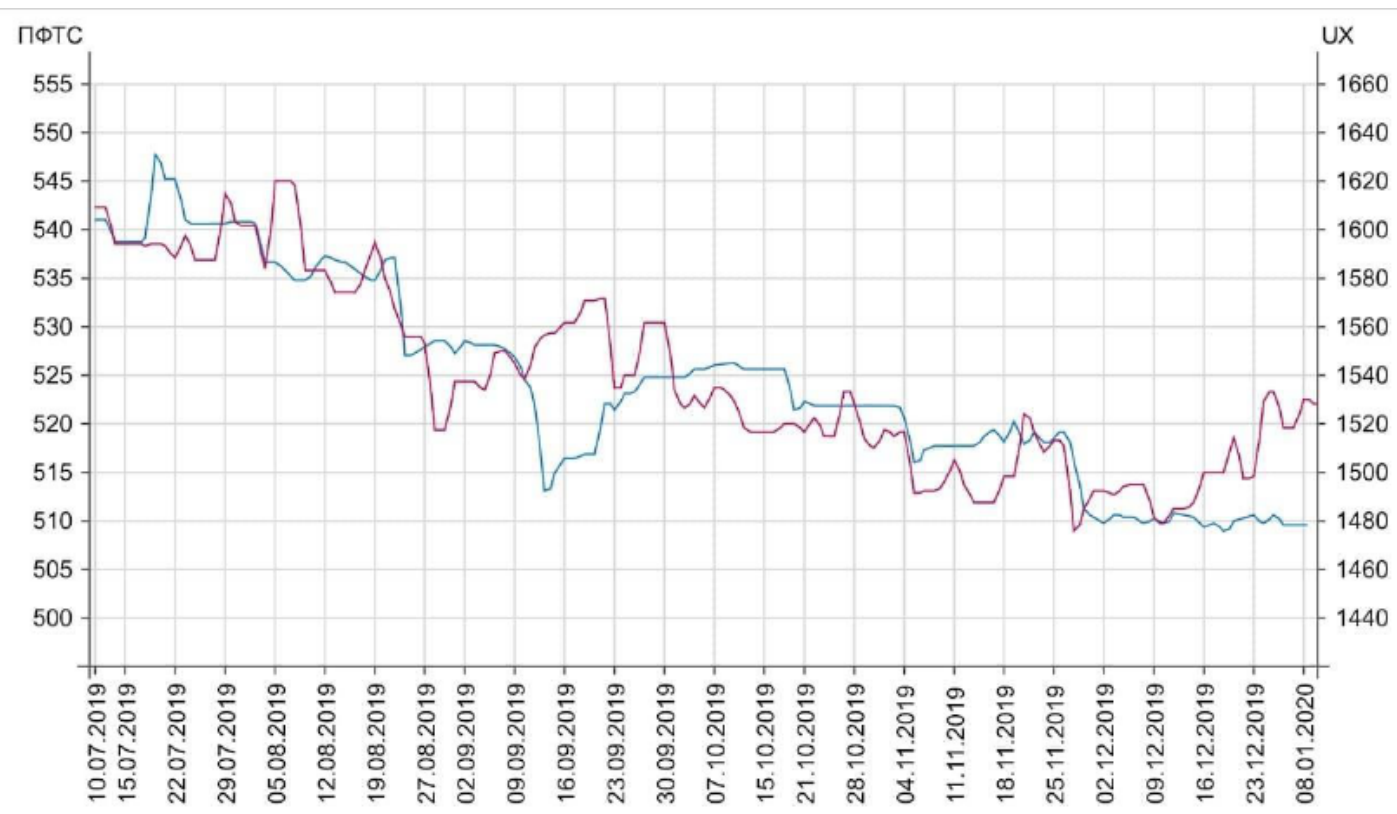

Figure 1 Dynamics of "PFTS" and "UX" Ukrainian Exchange Indexes (July, 2019 - January, 2020)

Taking the above-mentioned into account, progressive American experience on the functioning, regulation and criminal protection of the stock market might become both relative and instructive for Ukraine, especially in the context of identifying key vectors of the national economy and foreign economic relations. This is obvious due to the fact that today the United States is one of the key industrial centers of the world (together with China, the United States provide more than $1 / 3$ of world industrial production), a world center of scientific and technological progress and a global financial center (with more than $40 \%$ of global financial transactions made in U.S. dollars). Therefore, it is not surprising that the world's largest stock market (in terms of capitalization) is located in this country.

American approach to securities market regulation has traditionally relied on the transparency of information used by stock market participants. One of the key tasks of the Securities Acts of 1933 and the Stock Exchange Act of 1934 was to ensure that investors disclose certain economic information about the issuer of securities. This approach was aimed at creating a fair playing field for all stock market participants by providing all investors with the upmost free access to information. It had been decided to implement this approach by banning securities trading on the basis of material (essential) and non-public information.

With the introductory remarks serving as general background for this study, the article elaborates on some of the pressing issues of stock market enforcement related to the phenomenon of insider trading, or, to put it otherwise, insider fraud, within the framework of globalized securities transactions. Our analyses will be produced via comparative approach, with two jurisdictions, Ukraine and the United States of America, serving as virtual test grounds for the criminal law protection of national stock markets against illegal insider behavior.

\section{STOCK MARKET AS A PREDICATE ECONOMIC ENVIRONMENT FOR COMMITTING INSIDER TRADING AND RELATED MARKET OFFENSES}

Just like at any given time before, today national stock markets remain the territory of asymmetries and uncertainty, the zone of volatility and risk. Under conditions of permanent risk modification, accelerated speed of the dissemination of information and Fintech 
innovations, counteraction to conflicts of interest, fairness of pricing, protection of investor interests remain mandatory components of policy decisions and regulatory practices with respect to stock markets. However, even employing the best world practices and approaches does not guarantee reduction of risks and asymmetries within the stock market, enhancing its maturity and functional role in the national economy.

With the transition of Ukraine's economy to much more progressive market model, various securities became available in the country, they have formed the core of the stock market, which is recognized as an important element in the mobilization of national savings and their transformation into investment tools. Foreign experience demonstrates that financing of economic entities by issuing and circulating securities has significant advantages when compared to other forms of investment. In countries with developed market models, banks are losing their role as major creditors in favor of the stock market capital rising. The latter's development is considered an indicator of economic liberalization and successful market reforms, creates important component of the modern economic regulation, provides national economy with desired flexibility and mobility, and provides with the tools to quickly chanel resources between various industries and allows to structurally adjust economic productivity.

American stock market, its capitalization, number of stock related violations and other indicators are incomparably higher than the related data on Ukrainian stock market. For example, as of September 30, 2020, the total market capitalization of the U.S. stock market has been over 36 trillion dollars[1].

In 2018, the total volume of securities trading on Ukrainian stock market amounted to UAH 260.866 billion (approximately $\$ 9,3$ billion under the 2020 exchange rate). At the same time, trading in shares amounted to only UAH 1.18 billion (or $0.45 \%$ of the total), corporate bonds UAH 10.26 billion. (4\%), Government Bonds - UAH 245.73 billion (or 94.1\%), other securities - UAH 3.68 billion (1.4\%). In a striking comparision, on just one day, December 17, 2020, NASDAQ stock exchange hosted trading operations in the total dollar value of over \$238 billions [3]. To stress our point here, this has been just one-day volume at one of many U.S.based stock exchanges. The breathtaking difference in economic data explains differences in patterns and sheer number of insider trading criminal cases in Ukraine and the U.S.

Since Ukraine became an independent country in 1991, it has made some, though limited, progress in creating organizational and legal foundations for the functioning of the stock market, which has been enshrined at the legislative level in the form of the Law "On Securities and Stock Market", adopted on February 23, 2006. This Law has incorporated the elements of domestic and European stock markets and also provisions of the 2003 Civil and Commercial Codes of Ukraine.

Table 1 Major operation parameters of global and Ukrainian stock markets [4]

\begin{tabular}{|c|c|c|c|c|c|c|c|}
\hline \multirow{2}{*}{ Place } & \multirow{2}{*}{$\begin{array}{c}\text { Stock } \\
\text { Exchange }\end{array}$} & \multirow{2}{*}{$\begin{array}{c}\text { Capitalization, } \\
\text { December } \\
\text { 2018, USD, } \\
\text { billions }\end{array}$} & \multirow{2}{*}{$\begin{array}{c}2018 \\
\text { Trade } \\
\text { Volume, } \\
\text { USD, } \\
\text { billions }\end{array}$} & \multirow{2}{*}{$\begin{array}{c}\text { Stock } \\
\text { Market } \\
\text { Effectiveness, } \\
\%\end{array}$} & \multicolumn{3}{|c|}{$\begin{array}{c}\text { Total Number of Issuers, } \\
\text { December } 2018\end{array}$} \\
\hline & & & & & Total & Ukrainian & Foreign \\
\hline 1 & NYSE & 20679,5 & 19340,9 & 93,5 & 2285 & 1775 & 510 \\
\hline 2 & Nasdaq-US & 9756,8 & 16789,8 & 172,1 & 3058 & 2622 & 436 \\
\hline
\end{tabular}


Dmitriy V Kamensky, Olexandr O Dudorov, Roman O Movchan, Andrii A Vozniuk and Tamara P Makarenko

\begin{tabular}{|c|c|c|c|c|c|c|c|}
\hline 3 & $\begin{array}{c}\text { Japan } \\
\text { Exchange } \\
\text { Group }\end{array}$ & 5296,8 & 6296,9 & 118,9 & 3657 & 3652 & 5 \\
\hline 4 & $\begin{array}{l}\text { Shanghai } \\
\text { Stock } \\
\text { Exchange }\end{array}$ & 3919,4 & 6116,0 & 156,0 & 1450 & 1450 & - \\
\hline 5 & $\begin{array}{l}\text { Hong Kong } \\
\text { Exchanges } \\
\text { and Clearing }\end{array}$ & 3819,2 & 2340,2 & 61,3 & 2315 & 2161 & 154 \\
\hline 33 & $\begin{array}{c}\text { Warsaw } \\
\text { Stock } \\
\text { Exchange }\end{array}$ & 160,5 & 57,0 & 35,5 & 851 & 823 & 28 \\
\hline 66 & $\begin{array}{l}\text { Ukrainian } \\
\text { Exchange }\end{array}$ & 4,4 & 0,013 & 0,3 & 80 & 78 & 2 \\
\hline
\end{tabular}

It is worth adding that development of the stock market is conditioned by numerous factors, including the state of legislative will be aimed ar counteracting market offenses, primarily manipulation and insider strading. Indeed, stock market crimes and other torts (such as dissemination of manipulative and insider practices, issuance of "garbage" securities, fictitious issues, corrupt shemes in stock exchanges etc.) create various grounds for distrust by investors, increase investment risks and, as a result, worsen the investment climate, complicate formation of the market economy model in Ukraine, encroach on the interests of securities owners and other stock market participants, contribute to money laundering and lead to other negative consequences.

Among the causes of insufficiency and ineffectiveness of administrative and legal prohibitions: 1) danger of insider violation, the mechanism of which resembles sophisticated fraud; 2) degree of harm caused by such abuses far outweigh the average amount of the fine imposed as an administrative penalty; 3 ) implicit doubtfulness of establishing the fact of insider abuse within the proceedings in cases of administrative offenses and the consequent need for search, seizure and related criminal proceedings [5].

According to I. Klepitsky, criminal law prohibitions, while clearly delineating the boundaries of prohibited behavior and without interfering with the activities of law-abiding market participants, serve as the most liberal ("market") means of state influence on the securities market, while administrative and other similar methods of regulation can seriously damage national stock market [6].

Appeal to the special norms of the Criminal Code of Ukraine on liability for crimes against stock market and practice of their application (or more precisely - non-application, since vast majority of such provisions belong to the group of so-called "dead", or unused by law enforcement and courts, provisions) once again demonstrates that one of the negative trends in Ukrainian legislation on criminal liability for economic (and equated to them) crimes is a quantitative increase in the volume of legislative material, compared to virtually unchanged volume of criminalization, when the appearance of new articles in the Criminal Code does not actually lead to the expected increase in the number of criminal acts and, most importantly, to the desired effect. 
Ukrainian commentator V. Saenko points out that American model of outlawing abuse of insider information due to its complexity and instability can hardly be borrowed successfully by Ukraine. At the same time, it is useful to study principles of regulating usage of insider information, approaches to defining its concept, methods of detection and investigation of relevant offenses [7]. In comparision, in the United States special legislation aimed at combating insider abuse from the very beginning, and hence relevant law enforcement practice has started building up in 1930s. It is thus no coincidence that the United States is considered a jurisdiction, in which the issues of combating illegal usage of insider information have been addressed for the longest period of time.

Reflecting on the issues of effective combatting crimes in the securities market, G. Rusanov emphasizes the need for close cooperation of special government agencies with regulatory functions in the stock market with competent law enforcement agencies (their units), as well as the urgent need for advanced training of law enforcement officers in this area, including by actively exchanging experiences and data with law enforcement agencies of other countries, which have a solid record of criminal prosecution for crimes committed in the securities market. Such proposal seems rational and deserves a more detailed study with the ultimate goal of practical implementation when investigating and prosecuting stock market offenses [8].

For example, the U.S. Department of Justice's (DOJ) Market Integrity and Major Frauds Unit ("MIMF") focuses on the prosecution of complex and sophisticated securities, commodities, and other financial fraud cases. By cooperating with regulatory partners at the Securities Exchange Commission, SEC, Commodity Futures Trading Commission, and other agencies, MIMF has tackled some of the largest frauds in the financial services industry and a wide mix of market manipulation and insider trading cases [9].

\section{INSIDER TRADING UNDER UKRAINIAN CRIMINAL LAW: ELEMENTS OF CRIME, COMMON SCHEMES AND REGULATORY COLLISION ISSUES}

As rightfully mentioned in legal scholarship, one of the prerequisites for criminalization of acts related to professional activity in the stock market of Ukraine is the emergence of new types of financial instruments, introduction of Western regulatory models on the national securities market and lack of appropriate criminal law, which has inevitably led to fraudulent offenses. At the same time, critical study of the experience of countries with strong, active stock markets reveals that information disclosure is an effective tool of influencing the company and protecting investors' rights.

In his paper on the causes and consequences of such crimes, American author E. Malone writes that insider trading can destroy market integration by giving preference to an exclusive group of people, who have access to confidential information [10]. S. Dolgopolov substantiates, in turn, high risks of the loss of liquidity by the stock market and subsequent investment attractiveness due to insider trading transactions [11]. Indeed, even without special knowledge in the field of economics and stock market operation, it becomes obvious that "inflating" shares with unreasonable value due to the excitement caused by speculation with insider information contradicts market economy realities, when the market itself, being based on information supply and demand for all its participants, must adjust the value of the company. Possession of insider information for securities transactions becomes a type of passive deception: you earn money by concealing information, which should be available to everybodty else.

The bottomline here: information symmetry is fundamental to the proper functioning of the stock market: an array of information relevant to determining the value of securities must be equally accessible to all recipients. How a stock market participant interprets and uses such information is yet another thing. It is obvious that the informational advantage of an insider 
and, therefore, success of his activities in the stock market depends on the interpretation of information and expectations by other market participants. An insider enters into transactions with securities, hoping that other market participants will react to the subsequently disclosed information in the same way as he does, but he acts with a significant advantage timewise, which allows to obtain much more income from the securities exchange rate difference.

Instead, the misuse of insider information creates information asymmetry: sensitive, economically significant, and potentially "profitable" information is made available and subsequently used by several insiders (primary or secondary), thereby placing other interested stock market participants in obvious material disadvantage.

While continuing legal analyses of Ukrainian criminal liability model for insider trading, elements of the insider trading offense under the Criminal Code of Ukraine are worth covering as well.

Under part 1 of Article 232-1 "Illegal Use of Insider Information" of the Criminal Code of Ukraine (hereinafter - CC)[2], the relevant crime is constituted by the intentional illegal disclosure, transfer or provision of access to insider information, as well as by provision of such information recommendations on the acquisition or discharge of securities or derivatives (derivatives), if it led to the receipt by the perpetrator or third parties of unreasonable profits in a significant amount, or to avoidance by a stock market participant or third parties of significant losses, or if it has caused significant harm to the rights, freedoms and interests of individuals protected by law or state or public interests or the interests of legal entities. Also execution, with the use of insider information for their own benefit or for the benefit of others, of transactions aimed at the acquisition or alienation of securities or derivatives (insider information), to which the insider information relates, if it brought to the perpetrator or third parties unreasonable profits in a significant amount, or caused avoidance by a stock market participant or third parties of significant losses, or if it has caused significant damage to the legally protected rights, freedoms and interests of individuals or state or public interests, or the interests of legal entities, shall be criminally punishable as well (part 2 of Article 232-1 of the CC).

It is worth adding that many regulatory prohibitions correspond to the elements of crime, described in parts 1 and 2 of Art. 232-1 of the Criminal Code. This makes sense, since the obvious regulatory nature of the relevant criminal provision requires precise regulatory synchronization of the requirements established by a special legislative provision (imperative nature) with the legal grounds for criminal liability for their violation.

Providing recommendations as a specific criminal act referred to in Part 1 of Art. 232-1 of the Criminal Code, may relate to the actual fact of acquisition, alienation of securities or derivatives (i.e. manifested in advice to buy, sell relevant securities or refrain from selling or acquiring them) and the moment of taking appropriate action (advice to postpone purchase, sale of securities for a certain period of time or until a certain date) or the number of securities or derivatives, which are the subject of the relevant transactions [12].

Illegal use of undisclosed information on non-equity securities does not constitute discussed crime in Ukraine, even if such act caused significant damage by having a significant impact on the value of such securities. On the one hand, provision on insider violations, which relate only to equity securities, is consistent with the requirements of current domestic legislation on the stock market. On the other hand, taking into account European integration aspirations of Ukraine, regulatory legislation in this part should be brought in line with the Regulation (EU) No 596/2014 of the European Parliament and of the Council of 16 April 2014 on market abuse (market abuse regulation) and repealing Directive 2003/6/EC of the European Parliament and of the Council and Commission Directives 2003/124/EC, 2003/125/EC and 2004/72/EC. Therefore, according to academic commentators, definition of the term "insider information" 
should be expanded to include not only data about equity securities, but also about financial instruments into the concept of such information. Appropriate changes ought to be made to Art. 232-1 of the Criminal Code of Ukraine [13]. At the same time, when expanding the concept of insider information, it is necessary, among other things, to take into account I. Klepytsky's warnings about the dubious possibility of insider abuses to cover exchange trade in goods and unjustified, from the economic point of view, introduction of appropriate bureaucratic restrictions [6].

\section{AMERICAN MODEL OF COMBATTING INSIDER TRADING OFFENSES}

Critical view of insider abuse, regardless of the "nationality" of the criminal law, which contains relevant prohibitions, leads to the interpretation of insider activity as a specific form of fraudulent, anti-market behavior. Such model can be characterized by the following points: 1) there is an abuse of trust by the insider - a malicious violation of fiduciary obligations of insider loyalty primarily to shareholders and company's management (of course, if the board does not consist of insiders) through illegal use of insider information; 2) subject of insider abuse must be recognized as a special intangible object, which has (at least potentially) some material value - specific information of financial and economic nature with limited access; 3) primarilty selfish motivation of insider behavior; 4) complex mechanism of illegal use of insider information: insider abuses trust of some persons (shareholders, board members or other persons, who entrusted him with confidential information), and illegal material benefits due to the use of such information from others [14].

Now, turning to the relevant American legislative and enforcement experience, one should note that in contrast to the rules of special legislation of Ukraine and other European countries, no official definition of insider information exists the United States to dat. Being adopted pursuant to $\S 10$ (b) of the Stock Exchange Act of 1934, U.S. Securities Regulation 10b-5 (hereinafter Rule 10b-5) prohibits anyone, while selling or purchasing any security, directly or indirectly, by using any means or instruments of trade between states, or postal items or any object of any national stock exchange, to alternatively commit one of three acts: 1) use any method, scheme or method of fraud; 2) falsely report any material circumstance or conceal any material circumstance necessary for a true official statement; 3 ) engage in any act, conduct or business practice, which is or may be recognized as fraud or deception of any person in connection with the purchase or sale of any security.

In 1961, the US Securities and Exchange Commission ruled in an administrative case against brokerage firm "Caddy, Roberts \& Co.", proposed traditional approach to understanding prohibition on disclosure of insider information in the context of Regulation 10b5 application. The federal regulator's approach is based on two key points: 1) existence of relationships, which provide access, directly or indirectly, to information intended only for internal, corporate use, and not for personal use; 2) manifestation of obvious injustice in situations where a person benefits from the use of such information, recognizing that it is not available to other persons, with whom such person has business relationship [15].

Subsequently, American courts have developed this rule into a broader standard with the unofficial title "disclose or refrain". In the case of "SEC v. Texas Gulf Sulfur" (1968) the Court of Appeals for the Second Circuit described it as follows: any person, who possesses insider information, must either disclose it to the entire investor community, or if he is unable to disclose such information in order to protect corporate (commercial) secrets or simply does not want to disclose it, must refrain from trading in securities as long as relevent information remains undisclosed [16]. 
The following criminal case, indeed one of hundreds in American insider trading enforcement practice, reveals the zeal and effectiveness of the federal government in fighting such type of white colslar behavior.

In August 2012, Robert Ramnarin was accused of committing three episodes of securities fraud. As "Bristol-Myers Squibb" ("BMS") Deputy Secretary of the Stock Markets Department, Mr. Ramnarin analyzed financial condition of the companies in which "BMS" was interested. While bearing an obligation to the company not to disclose or use for its own benefit or for the benefit of third parties any material non-public information about the activities of "BMS", Ramnarin violated it by using insider information against the company interests. The investigation established that during 2010-2012 the accused, by using information with limited access, traded in securities of three companies. The total income, received by Ramnarin, amounted to 311,361 dollars [17].

Cyber-attacks posess obvious threat for the development of national stock markets, since they allow offenders to get access to sensitive insider information of material value [18].

\section{CONCLUSION}

Based on the comparative legal analysis of the insider trading offense, regardless of the "nationality" of criminal law, which contains relevant white collar provisions, insider activity should be defined as a special type of information fraud witin economic relations. Proposed definition is explained by the following factors: 1) abuse of trust by the insider - a malicious violation of the fiduciary obligations of the insider to act in the interests of shareholders and the company itself in the face of management, through illegal use of insider information; 2) insider trading targets special intangible object, which has, at least potentially, some material value specific economically significant information with limited access; 3) primarily "self-dealing" motivation of insider's behavior, which is desire to get rich by using information when buying / selling securities; 4) complex mechanism of illegal use of insider information is implemented: insider abuses explicit or implicit trust of some persons (shareholders, government officials, developers or other persons, who entrusted him with confidential information), and receives illegal material benefits from the use of such information from others.

Degree of effectiveness of criminal law protection of Ukrainian stock market largely depends, among other things, on the quality of the law on combating illegal use of insider information and also on the substance of the relevant regulatory legislation rules. Despite some shortcomings, current version of Art. 232-1 of the Criminal Code of Ukraine generally allows for a proper criminal assessment of insider abuse. In particular, just like in the United States, Ukrainian insider rule takes into account the need to protect information symmetry, which is fundamental to the proper functioning of the stock market: an array of information relevant to determining the value of securities must be equally accessible to all recipients. The lack of specific law enforcement practice in Ukraine is explained by the internal characteristics of the national stock market, by its currently undeveloped status.

\section{REFERENCES}

[1] Ukrainian Stock Exchange Indexes. Minfin. https://index.minfin.com.ua/markets/stock/

[2] Koshoviy, O.G., Tertishnik, V.M., Sheludko, N.M. (Eds.) Abuse in the capital market: economic and legal aspects. Dnipro: LIRA, 2019. 532 p.
Nasdaq
Daily
Market
Summary.
Nasdaqtrader.com. http://www.nasdaqtrader.com/Trader.aspx?id=DailyMarketSummary

[4] Shtefan, L.B., Macedonska, N.V. Securities Market Development Trends in Ukraine. Money, Finances and Credit, 42, 2020, pp. 338-345. https://doi.org/10.32843/infrastruct42-57 
[5] Kamensky, D.V. Liability for Economic Erimes in the United States and Ukraine: Comparative Legal Study: a monograph. Kyiv: "Dakor" Publishing House, 2020. 1128 p.

[6] Klepitsky, I.A. Insider Information and Criminal Law. Law, 9, 2011, pp. 67-79.

[7] Saenko, V.V. Legal Regulation of the Use of Insider Information in Securities Market. Abstract of PhD thesis. Kyiv: Kyiv National University Named After Taras Shevchenko, 2002. 18 p.

[8] Rusanov, G.A. Crimes in the Securities Market: Monograph. Moscow: YURKOMPANI, 2011. $160 \mathrm{p}$.

[9] Market Integrity and Major Frauds Unit. United States Department of Justice. https://www.justice.gov/criminal-fraud/market-integrity-and-major-frauds-unit

[10] Malone, E. Insider Trading: Why to Commit the Crime from a Legal and Psychological Perspective. Journal of Law and Policy, 12, 2003, pp. 327-368.

[11] Dolgopolov, S. Insider Trading and the Bid-Ask Spread: A Critical Evaluation of Adverse Selection in Market Making. Capital University Law Review, 33, 2004, pp. 83-180.

[12] Melnyk, M.I., Khavronyuk, M.I. (Eds.). Scientific and Practical Commentary on the Criminal Code of Ukraine. 10th ed. Kyiv: Dakor, 2018. 1387 p.

[13] Volynets, R.A. Criminal Law Protection of the Stock Market. Doctor of Law thesis. Kyiv: Kyiv National University Named After Taras Shevchenko, 2018. 461 p.

[14] Dudorov, O.O., Kamensky D.V. Insider Information and Criminal Law: From American Realities to Ukrainian Perspectives. Legal Scientific Electronic Journal, 3, 2019, pp. 185-201 http://www.lsej.org.ua/3_2019/52.pdf

[15] Cady, Roberts \& Co., 40 S.E.C. at 912. URL: https://insidertrading.procon.org/sourcefiles/CadyRobertsCo.pdf

[16] SEC v. Texas Gulf Sulfur Co., 401 F.2d 833 (1968) (en banc).

[17] Bristol-Myers Squibb Executive Arrested on Insider Trading Charges. Federal Bureau of Investigation. http://www.fbi.gov/newark/pressreleases/2012/bristol-myers-squibb-executivearrested-on-insider-trading charges

[18] Sullivan, J.E, Kamensky D. How cyber-attacks in Ukraine show the vulnerability of the U.S. power grid. The Electricity Journal, 30, 2017, pp. 30-35. http://dx.doi.org/10.1016/j.tej.2017.02.006

\section{KEY NOTES}

1. The market value is the total market cap of all U.S. based public companies listed in New York Stock Exchange, Nasdaq Stock Market or OTCQX U.S. Market. During the year 2019 alone, the total market value of American companies has increased 25.2\%. Between January 1, 2010 and December 31, 2019, the market cap of U.S. corporations has increased $149.9 \%$.

2. Article 232-1 was incorporated into the text of the Criminal Code of Ukraine in 2006. 